\title{
Effect of Magnetotron on the Rates of Growth and Fecundity in Ostracoda Cyprislaevis O.F Müller,1776 under the Laboratory Conditions تأثير المغنايتوترون في معدلات النمو والخصوبة في الدرعي Cyprislaevis O.F.Müller,1776 تحت الظروف المختبرية
}

\author{
Qater Al-Nada Ali Kanaem Al-Ibady \\ College of Health and Medical Technology \\ Foundation of Technical Education \\ قطر الندى علي غانم العبادي \\ كلية التقنيات الصحية والتطبية- هيئة التعليم التقني
}

\begin{abstract}
The Magneototron technique considers as recent and advanced techniques in magnetic water treatment, which application in different; ecological, agricultures, industrial, medical and scientific fields. Therefore this study making to determine the effects of Magnetotron system with different intensities $0.05,0.10$ and 0.15 Tesla on some biological aspects for one species of freshwater Ostracoda cyprislaevis O.F. Müller, 1776 for economical important, because both juveniles and adults of fishes feeding on it and as a tool for water cleaning, which consideration feeding on dead and decay animals and vegetables The samples of Ostracoda were collected from Al-Jaesh canal- Baghdad province for period from 1/9/2012 to 1/11/2012.The obtained results compared with this species of Ostracoda which lived in raw water (unexposed to magnetotron system).The present study demonstrated increased significance the rates of growth by increased the bivalve carapace dimensions (length and width) for both ostracodean males and females with increased intensity of magnetotron system comparative with untreated water. Although increase significant observed in fecundity in ostracodean females by increase the number and diameter of eggs with increased intensity comported with untreated females. Also this study detected to predominant females upon males in both treated and untreated water with magnetotron system. Then the magnetotron system does not effect on heterogonous in sexual formation for this species in same ecosystem.
\end{abstract}

Key wards: Magnetotron, Rates of Growth and Fecundity, Ostracoda cyprislaevis

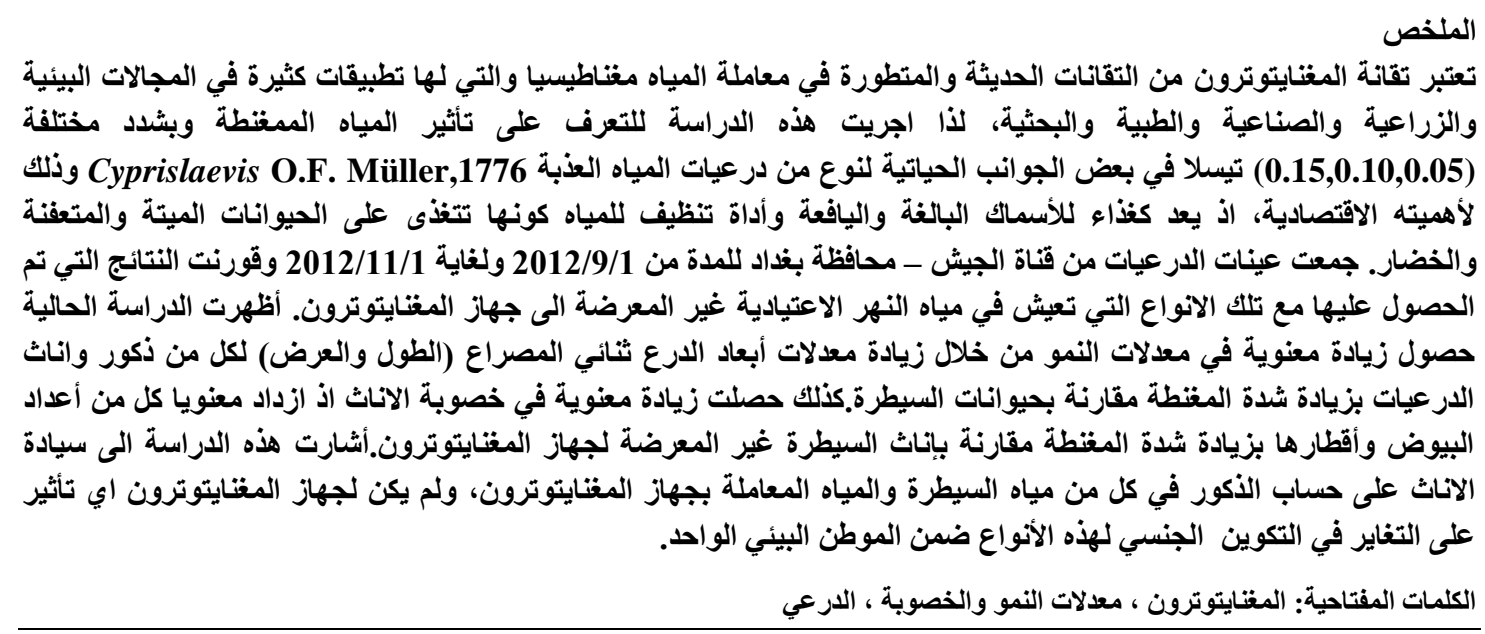

Introduction

Ostracodas are small aquatic crustaceans that secrete shells or valves made of calcite, which are often preserved in quaternary sediments [1]. Therefore can be efficiently used as indicator species for interpreting water quality of different aquatic habitats [2]. Ostracods are small, poorly-segmented entomostracan. Crustacea in which the body parts are enclosed with in a calcareous bivalve carapace [3]. Cyprislaevis refers to the family Cyprididae. This species living in littoral lakes and spring, can consider as indicate submerged vegetation. It tolerates a wide range of environmental conditions in littoral [4]. A number of species were reported to be sensitive to magnetic fields, and could potentially be affected by EM fields created by wave energy devices and cables [5]. Therefore the aim of this study 
to investigate the effects of magnetotron system with different intensities on the growth and fecundity of freshwater ostracodas pecies under laboratory condition.

\section{Materials and Methods}

Ostracods and their eggs live in it, to three different intensities, 0.05,0.1 and 0.15 Tesla under laboratory conditions. The obtained results comparative with those in untreated water (control). In this study 4 plastic bakers used, the first for control, the 2 nd for $0.05 \mathrm{~T}$, third for $0.1 \mathrm{~T}$ and finally 4 th for $0.15 \mathrm{~T}$. The feeding of species occur every 2 days by leaves of plants such as vegetables. Firstly exposure the samples to magnetron system every 24 hours, which were calibration and give it three magnetized intensities by using the Gauss meter type F.W. Bell/Gauss Model 5070, USA. Full weekly recorded, the carapace dimensions of males and females, then also recorded the number and diameter of eggs until end there life span, by using the compound microscope type PROWAT-CH China origination, with measured ocular lens on $4 \mathrm{X}$ magnification. Until end life span of it. The results comparative with those in control. Finally the results analysis by using SAS program [6] to find the data means, stander deviation and stander error. Also using chi-squire to finding sex-ratio for species in both treated and untreated water.

\section{Results}

The figures $(1,2)$ showed higher values of carapace's length and width for males, which were 27, 23.2 $\mu \mathrm{m}$ for $0.1 \mathrm{~T}$ in respectively, with age 7 weeks. But the lowest values of carapace's length and width for males, which were $22,14.8 \mu \mathrm{m}$ for 0T (control) in respectively, also with age 7 weeks. While the figures $(3,4)$ showed higher values of carapace's length and width for ostracod's females , which were 27.1,23.4 $\mu \mathrm{m}$ for $0.1 \mathrm{~T}$ in respectively, with age 7 weeks. But the lowest values of carapace's length and width for females, which were 22.6, $14.4 \mu \mathrm{m}$ for 0T (control) in respectively, also with age 7 weeks. Finally the growth of carapace was increased significantly with increased magnetized intensity, especially with 0.1T.The figure (5) demonstrated the number and diameter of ostracod'seggs, which were increased significantly with increased magnetized intensities. Therefore the highest value of eggs which obtained in this study, which were 57 in both $0.05 \& 0.1 \mathrm{~T}$ in respectively, but was 56 eggs in $0.15 \mathrm{~T}$. While the highest diameter which obtained was $4.6 \mu \mathrm{m}$ with $0.15 \mathrm{~T}$. Then the number and percentage of males and females of freshwater ostracods which detection in figure (6), wherever the results in this study were no found different significances to sex ratio of Cyprislaevis, but occur dominance the females on males, because the highest number and percentage of females were obtained in both treated and untreated water with magnetotron syste, which were $17(68 \%)$ for females in both control and $0.15 \mathrm{~T}$.

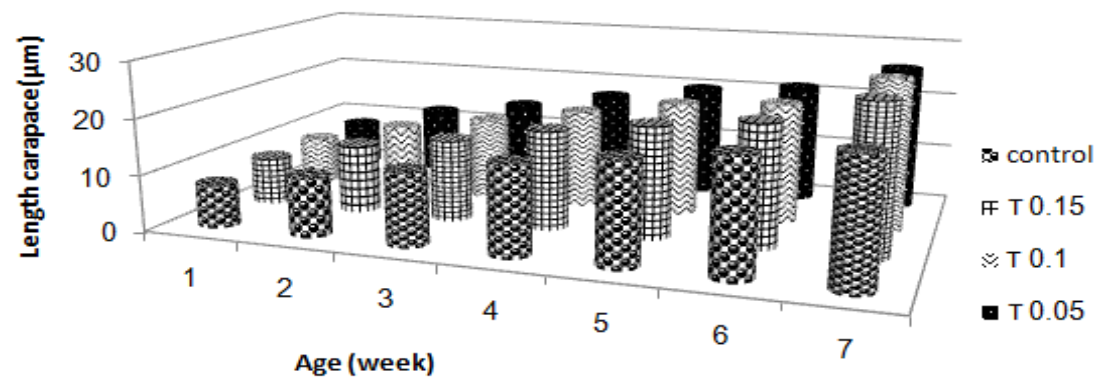

Figure (1): Carapace's length of Cyprislaevis males in control and magnetized water

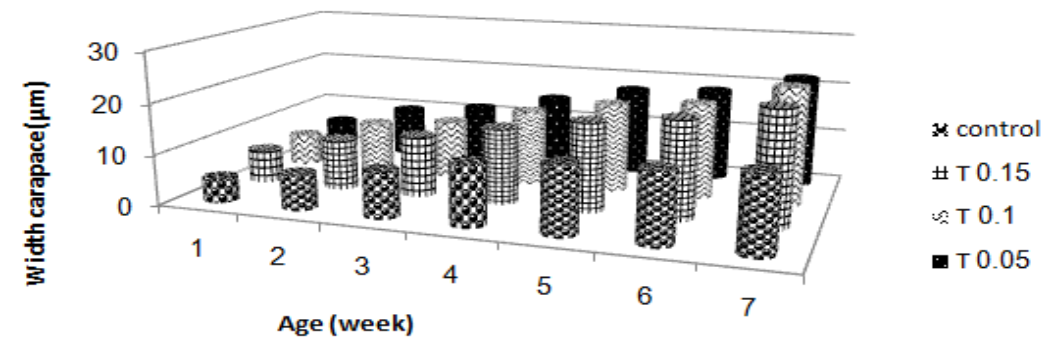

Figure (2): Carapace's width of Cyprislaevis males in control and magnetized water 


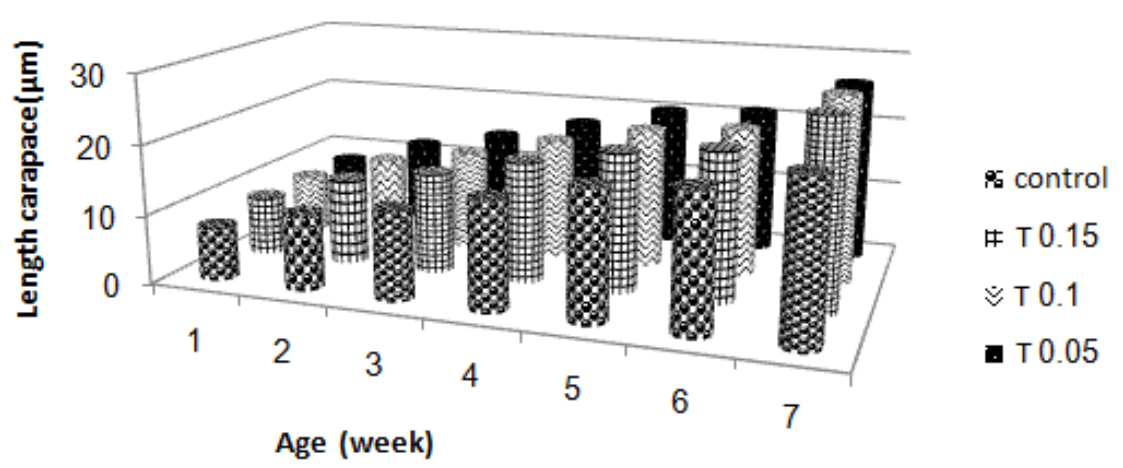

Fig.(3): Carapace's length of Cyprislaevis females in control and magnetized water

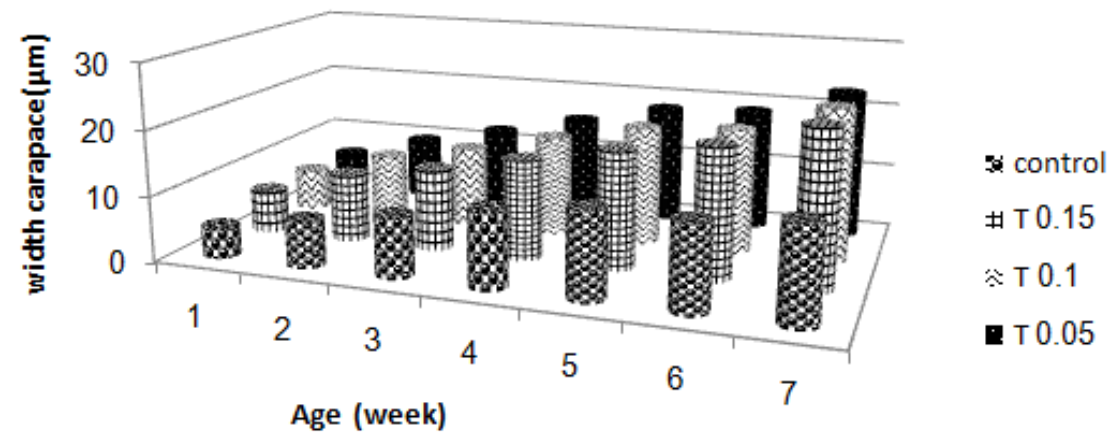

Fig.(4): Carapace's width of Cyprislaevis females in control and magnetized water

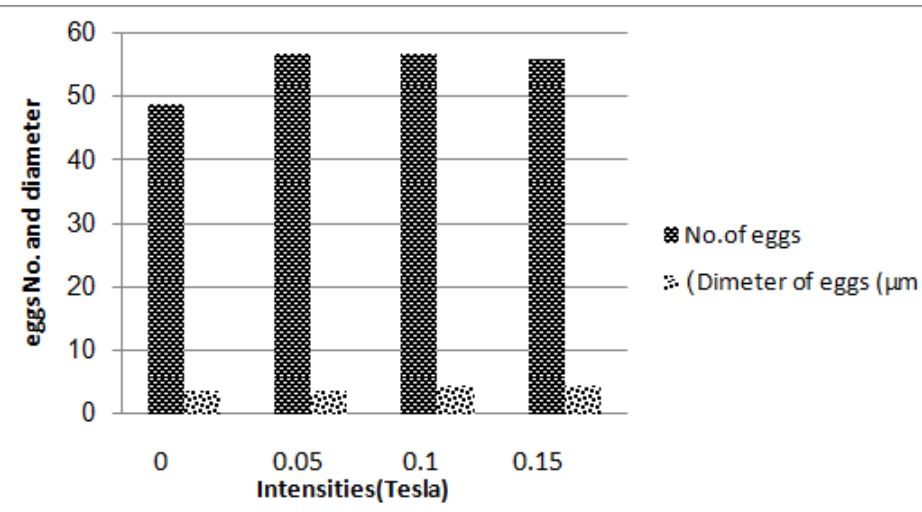

Fig.(5): Number and diameter of Cyprislaevis eggs in control and magnetized water

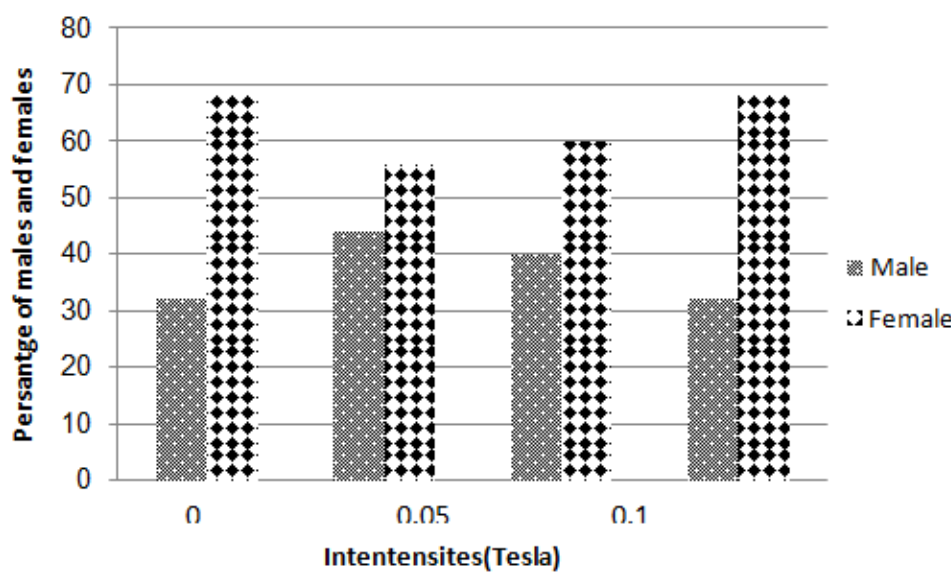

Fig.(6): Number and diameter of males and females Cyprislaevis in control and magnetized water 


\section{Discussion}

The ostrastracoda preference for sediments rich in organic matter to development rate and carapace calcification [7].Therefore in this study occurs increased in carapace dimension with increased intensities, this refers to effects of magnetic fields on ion flux through cell membranes. Also increased flow or movement of calcium ions and other materials within magnetic field and could effect on membrane's fluidity or other properties. It only takes a very low intensity magnetic field to effect on chemical reactions and these reactions have a definite biological effect on the body [8]. This results agreement with [9]. When whom investigates utilizing material with chitinous preservation of the appendages and carapace. The results of this study indicated that occurs increased in number and diameter of eggs with increased intensities of magnetized water. This because the magnetized water content such as oxygen which plays an important role in a wide variety of living systems. And occurs increased enzymes activity, and conformational changes of the cellular membrane by potential effect of magnetic field altering the influx of nutrients into eggs and efflux of waste products[8]. This results agreement with [10] When who treated the dry winter eggs of Artemiasalina with a 30-60T in homogenous constant magnetic field for $113 \mathrm{~h}$, he noticed after 8 days early development rate and hatching rate.The females dominate the males in number, this may be because the local environmental conditions, mainly salinity and $\mathrm{PH}$ as well as diversity [11]. The results agreement with [12] when he suggest that the unbalanced in sex ratio of some of ostracoda species could be caused at least partly by environmental conditions.

\section{References}

1. Holmes, J.A. and Chivas, A.R. (2002).The Ostracuda: Applications in Quaternary Research. Geophysical monograph series. vol.131: 313.

2. Konx, L. W. and Gordon, E. A. (1999). Ostracodes as indictors of brackish water environments in the cat skill Maganafacies (Devonian) of New York StatoPalaeogeog. Palaeclimat. Palaeoecol. 148:9-22.

3. Griffiths, H.I. and Evans, J.G. (1999). Some freshwater Ostracods (crustacean: ostracoda) from south wales. 64-72.

4. Pipik, Radovan and Bubik, Miroslav. (2006). Quaternary fresh water ostracode fauna from Kramuvir (Czech Republic). Scripta Fac. Sci. Nat. Univ. Masaryk. Brunensis. 33-34(2003-2004) :62-64, Geology. Brono.

5. Salter, Michael. (2010). Electromagnetic Field Study (Effects of Electromagneticfields on marine species: A literature review). Prpared by Cameron Fisher. On behalf of Oregon wave energy trust. p:123.

6. Statistical Analysis system (SAS). (2010). User's Guider Statistical Version 7th ed. SAS. Inst. Inc. Cary. N.C. USA.

7. Tabucchi, E. and Marmonier, P. (1994). Dynamics of the interstitial ostracod assemblage of apond in the Adour alluvial plain. Archi U. fur. Hydrobiologie. 131: 321-340.

8. Roberts, Drcraig and Bosch, Andrew. (2008). The effects of magnetism on physiological parameters and implications for athletic performance. International sport Meel. Journal. 9(3): 83-107.

9. Matzke - Karusz, Renat, Smith, Robin J. and Homma, Masayoshi. (2004). CyclocyprisdiebeliAbsolon, 1973(ostracoda, crustacean), extinct in Europe, extant in Japan. Journal of Natural History. 38(Issue 13): 1635-1663.

10. Xing, G.R., Zheng, D.C., Zhou, Q.L., Su, R.Z. and Chen, Q.E. (1991). Effect of Pre-flight Treatment with Constant Magnetic Field on Development of Artemia Eggs Retrieved from Chinese Satellite "8885". Sci. China B. 34(6): 699-705.

11. Martins, Maria João Fernandes, Vandekerkhove, Jochen, Mazquita, Francese, Schmit, Olivier, Rueda, Juan, Rossetti, Giampaolo and Namiotko, Tadeusz. (2009). Dynamics of sexual and parthenogenetic populations of Eucyprisvirens (crustacean: ostracoda) in three temporary ponds. Hydrobiologia. 636: 219- 232.

12. Namiotko, Tadeusz, Danielopol, Dan L. and Baltanás. (2011). Soft body morphology, dissection andslide. Preparation of ostracoda: a primes. Joannce Geol. Paläont. 11: 327- 343. 